\title{
mundo lá fora: \\ O cinema direto e o novo jornalismo
}

Julio Bezerra*

Artigo recebido em:

11 de março de 2010

Aprovado em:

24 de setembro de 2010

* É doutorando

em Comunicação

pelo PPGCOM/

UFF. Mestre em

Comunicação

e Cultura pela

ECO-UFRJ, com

especialização em Cinema

Documentário

pela FGV, e possui graduação em

Comunicação pela PUC-Rio. Atualmente é repórter e crítico de cinema na Revista de

Cinema.

juliocarlosbezerra@hotmail.com
Resumo: A proposta desse artigo é traçar um movimento de aproximação e estranhamento entre o cinema direto e o novo jornalismo americanos. Ambos os movimentos foram fortemente influenciados pela literatura realista de Flaubert, Dickens e outros; fizeram uso de recursos ficcionais para tratar de fatos e personagens; alimentaram questionamentos éticos; e se afirmavam a partir de uma série de premissas a respeito do "real". Em uma tentativa de capturar a realidade por meio de novos formatos, jornalistas e cineastas chamaram a atenção para os seus processos e estilos. De um lado, essas experimentações pareciam radicais; mas, do outro, por mais revolucionários que pudessem parecer, os movimentos funcionavam a partir de uma visão conservadora e tradicional do que vem a ser o "real" e a possibilidade de representá-lo.

Palavras-chave: Documentário; jornalismo; realismo.

\section{The outside world: \\ The direct cinema and the new journalism}

Abstract: The purpose of this article is to trace a movement of approach and estrangement between direct cinema and new journalism. Both movements were strongly influenced by the realistic literature of Flaubert, Dickens and others; made use of resources to deal with fictional events and characters; fueled ethical questions; and justified themselves from a number of assumptions about the "real". In an attempt to capture reality through new formats, journalists and filmmakers draw attention to their processes and styles. On the one hand, their strategies seemed radical, but on the other, these movements were operating from a conservative and traditional view of what is the "real" and the possibility to represent it.

Keywords: Documentary; journalism; realism. 

o final dos anos 50, novos equipamentos e técnicas de filmagem descortinaram possibilidades inéditas para o cinema documentário. As câmeras leves e os aparelhos de registro do som direto permitiram aos realizadores uma aproximação mais íntima com seu objeto e diminuíram a intervenção dos processos de filmagem sobre o meio documentado. Entre os movimentos que estabeleceram novas formas de abordagem da realidade e revigoraram o documentário está o cinema direto americano, cujo núcleo principal se deu em torno da produtora Drew Associates, fundada pelo repórter fotográfico Robert Drew e pelo cinegrafista Richard Leacock. Eles negavam a tradição professoral e militante do documentário. Desejavam filmes que fossem urgentes, capazes de flagrar a vida desarmada.

O cinema direto é em geral associado ao jornalismo. Autores de ambos os campos costumam sublinhar a influência que o cinema direto exerceu sobre o jornalismo televisual. De fato, o movimento americano estabeleceu padrões estéticos e apontou soluções narrativas para o telejornalismo então em formação. No entanto, este cinema só exerceu suas potencialidades quando figuras como Leacock, D.A. Pennebaker e Albert Maysles deixaram a Drew Associates e se tornaram realizadores independentes, rejeitando o formato rígido da TV. Sílvio Da-Rin (2004) sublinha que os realizadores do cinema direto preferiam usar expressões como "cine-reportagem" ou "jornalismo filmado" para descrever seus filmes, embora o próprio Drew ${ }^{1}$ tenha especificado em diversas ocasiões a que tipo de jornalismo ele desejava se alinhar. Brian Winston (2005) advoga que os realizadores do direto teriam substituído a função de "tratamento criativo da realidade" por um objetivismo extremado, embora Frederick Wiseman e os irmãos Maysles ${ }^{2}$ fizessem um cinema essencialmente de montagem e admitissem a condução do público em direção a determinados sentimentos e conclusões.

$\mathrm{Na}$ verdade, o cinema direto encontrava paralelo nesta mesma época em um movimento do jornalismo impresso: o novo jornalismo. Impulsionado pela publicação, na revista "The New Yorker", do primeiro dos quatro capítulos da reportagem "A sangue frio", de Truman Capote - posteriormente publicada em forma de livro reportagem -, o novo jornalismo é um movimento de ruptura e ampliação da atividade jornalística. Um jornalismo de imersão do repórter na realidade, em busca de novas estratégias narrativas que dessem conta dos conflitos e das micro ficções cotidianas.

$\mathrm{O}$ novo jornalismo e o cinema direto americanos desenvolveram fortes aproximações ético-estéticas com a realidade contemporânea, mas permaneceram isolados um do outro enquanto reflexão. Além de uma tese de doutorado americana ${ }^{3}$, ninguém parece ter explorado essa relação de maneira mais sistemática. Mas as conexões estão por aí: Robert Drew era fã confesso de Ernie Pyle, D.A. Pennebaker trabalhou com o jornalista Norman Mailer em filmes

\footnotetext{
'Drew diz: "Na TV, os noticiários noturnos, por exemplo, são um 'modelo', e fazem o que melhor se pode fazer nesse 'modelo', que é ordenar as notícias e informações. $O$ documentário teria de ser diferente". DREW em NIEMAN REPORTS, 2000: 45.

${ }^{2}$ Os irmãos Maysles falaram da importância da montagem para o cinema deles em diversas ocasiões. Entre elas, está uma entrevista ao crítico Jack Krool, um dos materiais extras do DVD de "Caixeiro viajante".

${ }^{3}$ ZUBER, 2004
} 
ficcionais, Albert e David Maysles fizeram um documentário sobre Truman Capote. Em entrevista a João Moreira Salles ${ }^{4}$, A. Maysles explica que o que eles almejavam com seus filmes tinha uma ligação direta com o seminal "A sangue frio" de Capote: "O que fizemos no cinema direto estava em paralelo ao que Capote fez na forma literária”.

\section{$\mathrm{O}$ cinema direto americano}

No início da década de 50, Robert Drew era editor de imagens da revista "Life". Sua função era pautar fotógrafos, sugerindo-lhes como traduzir visualmente uma história. Toda semana ele abria a revista e via imagens de Robert Capa, Henri Cartier-Bresson, Alfred Eisenstadt e Thomas McAvoy, e tinha a sensação de ser transportado para junto da ação. Drew decidiu então trazer para o documentário o tipo de fotografia espontânea que se acostumara a ver na "Life".

Em 1954, conheceu Richard Leacock, um jovem cinegrafista que já havia trabalhado com Robert Flaherty ("Louisiana Story"). Juntos, entenderam que não haveria revolução de linguagem sem uma revolução tecnológica. $\mathrm{O}$ equipamento disponível na época era gigantesco: tripés de carvalho maciço, gravadores do tamanho de uma mesa, luzes e um caminhão-baú repleto de cabos. Uma coisa era sair na rua com uma Leica no bolso, outra completamente diferente era aterrizar na cena com um caminhão de equipamento.

Os dois uniram forças na invenção de um novo cinema documental e se cercaram de figuras como D. A. Pennebaker e Albert Maysles. Em 1959, eles formariam a produtora Drew Associates com a intenção de produzir o que chamavam de um "jornalismo filmado". Segundo Drew, "documentários em geral, com muito poucas exceções, são falsos, (...) de certo modo eles lembram bonecos". ${ }^{5}$ O que tornava os documentários falsos, na visão de Drew e Leacock, não era somente a encenação, prática corrente no jornalismo audiovisual, mas, sobretudo, a narração e a música que costumavam ser utilizadas para dar mais espessura dramática à produção.

O segundo obstáculo de Drew dizia respeito à narrativa: "Percebi que os documentários tradicionais não passavam de palestras ilustradas. Era importante substituir a lógica da palavra pela lógica do drama. Só assim eu poderia criar um novo jornalismo. Como seria esse jornalismo? Seria como um teatro sem atores, como peças sem autores, como reportagens sem opinião". ${ }^{6}$ Para solucionar esse dilema, Drew pediu um ano de licença à revista e foi estudar técnicas narrativas em Harvard. "Durante o ano em que estive em Harvard, em 1955, eu me foquei em duas questões: Por que os documentários são tão chatos? O que teria de ser feito para torná-los interessantes e excitantes? Eu precisava partilhar uma experiência",

Sua primeira descoberta se deu pela estrutura do romance realista, em especial o "Madame Bovary" de Flaubert. Drew compreendeu que o melhor

"Extra do DVD de "Caixeiro viajante".

${ }^{5}$ CITADO por DA-RIN, 2004: 137.

"Faixa extra do DVD de "Primárias".

7 DREW em NIEMAN REPORTS, 2000: 45 
seria filmar não fatos, mas processos em que os indivíduos se veem obrigados a fazer escolhas cruciais. Ele denomina esse formato de estrutura de crise - a espinha dorsal de todo filme da fase inicial do cinema direto.

Com Flaubert, Drew também entendeu que as pessoas se revelam detalhe por detalhe. Ou seja: era preciso incorporar à narrativa tudo que até então ficara à margem dos documentários convencionais. Os filmes deveriam buscar o realismo em uma sucessão de tempos mortos: as esperas, os sonos, as filas, os apertos de mão, as conversas fiadas. Drew chamava atenção para a necessidade de um olhar para esses micro acontecimentos cotidianos, organizados em uma estrutura dramática capaz de seduzir e prender o espectador a uma história.

O cinema direto americano buscava comunicar um sentido de acesso imediato ao mundo, situando o espectador na posição de observador ideal. Inspirado em sua atuação anterior no campo do jornalismo e nas atualidades dos irmãos Lumière, Drew defendia a não-intervenção na cena por intermédio de métodos que pretendem colocar o espectador em contato direto com a realidade. Esse espírito de observação, tanto na montagem e na pós-produção como durante a filmagem, resultavam em um formato sem narrador, sem entrevistas, sem roteiro, sem música ou efeitos sonoros complementares, e sem reconstituições.

Em 1960, com grande parte do equipamento à mão - a câmera e o equipamento de som ainda estavam ligados por um cabo -, Drew pediu aos então senadores Hubert Humphrey e John Kennedy para acompanhá-los por cinco dias pelo interior do Wisconsin, durante a campanha do Partido Democrata às eleições presidenciais daquele ano. $\mathrm{O}$ método de filmagem interditava todas as formas de intervenção: "nós não pedimos às pessoas para agir, não lhes dizemos o que devem fazer, não lhes fazemos perguntas". ${ }^{8} \mathrm{E}$ os realizadores se dividiram em

O cinema direto
estabeleceu
padrões estéticos
e apontou soluções
narrativas para
o telejornalismo
então em formação
equipes reduzidas ao mínimo indispensável: "queríamos suprimir os diretores, a iluminação, as equipes técnicas habituais e tudo o que pudesse alterar a realidade que nós desejamos filmar".

Nascia "Primárias", o primeiro filme do movimento. Está tudo ali: a representação não-mediada, os tempos fracos, a estrutura de crise, etc. Mas embora tudo soasse bem diferente, "Primárias" ainda apresentava uma gramática em desenvolvimento, fazia uso da locução e carecia de uma estrutura dramática mais delineada. Na verdade, o cinema direto só cumpriria suas promessas quase uma década mais tarde, longe do âmbito televisivo. Pouco depois, Leacock, Pennebaker e Albert Maysles deixariam a Drew Associates e se tornariam realizadores independentes. Todos rejeitavam o formato rígido e os constrangimentos da televisão (ritmo acelerado, exigência de narração, minutagem rígida, etc).

Primeiro veio "Dont look back" (1967). Pennebaker recebeu do empresário de Bob Dylan (Albert Grossman) um convite para acompanhar uma turnê do cantor pela Inglaterra. Financiado por Pennebaker e Leacock, o projeto trazia a oportunidade de dirigir um documentário para o cinema. $\mathrm{O}$ cineasta viajou

${ }_{8}^{8}{ }^{9}$ CITADO por DA-RIN, 2004: 138. 
com Dylan por três semanas, filmando em táxis, coletivas de imprensa, lojas, bastidores de shows, e quartos de hotel. "Dont look back" nos deixa com a sensação de estarmos presentes no momento em que as coisas acontecem. Ao contrário do que pretendiam alguns críticos e cineastas do cinema direto, Pennebaker busca se envolver com o que filma. A ideia não é desaparecer no set, mas fazer parte dele. E não há exatamente uma progressão dramática. Muito pelo contrário. É como se o filme - antes mesmo de revelar um retrato do artista e da complexa década de 60 que o circunda - falasse do encontro entre Dylan e Pennebaker.

Neste mesmo ano, Frederick Wiseman, o único dentre os mestres do cinema direto que não teve passagem pela Drew Associates, lançava "Titicut follies" (1967). Neste filme, sobre o dia a dia do manicômio judiciário de Bridgewater, em Massachusets, Wiseman aponta um novo caminho para o cinema direto. As técnicas de filmagem de Wiseman buscam diminuir ao máximo a influência da equipe sobre o meio documentado. Seus documentários têm marcadamente uma função política e de denúncia dos mecanismos e efeitos da burocracia americana. "Titicut follies" não trabalha com personagens, não apresenta um desenvolvimento narrativo. O filme termina como começou. No entanto, a montagem assegura um ponto de vista e a missão de revelar as microrrelações de poder no interior da instituição e a hipocrisia da sociedade americana.

Dois anos depois, era a vez de Albert e David Maysles expandirem o vernáculo do movimento. Em "Caixeiro viajante" (1969), os realizadores acompanharam o trabalho de vendedores de bíblia. Dentre eles, Paul Brennan é pego em meio a um dilema existencial, preso entre um trabalho sem sentido e seus sentimentos. Uma crise mais nuançada do que as que o cinema direto se acostumara a documentar. Os irmãos Maysles explorariam mais a fundo outras estruturas dramáticas, seja se livrando de vez dos momentos de crise "Gimme Shelter”), seja sendo convocados a participar e tomar posições diante de seus personagens ("Grey Gardens").

Os irmãos Maysles refletem a influência de Drew ao mesmo tempo em que expandem as possibilidades estruturais do cinema direto. Alguns de seus documentários não apresentam exatamente um desenvolvimento dramático, não são dependentes de momentos de crise. Se por um lado Pennebaker nunca alcança os níveis de intimidade que os irmãos Maysles, por exemplo, constroem em relação a seus personagens, do outro, ele sabia como ninguém filmar concertos. Pennebaker trouxe uma postura mais intuitiva ao cinema direto, alimentando uma certa "energia espiritual" 10 no contato com os músicos. Wiseman trabalhou sozinho na confecção de uma postura mais radical dentro do cinema direto, mantendo um forte controle narrativo. Ele e os irmãos Maysles ainda sinalizaram a importância que a montagem passou a ter no cinema direto. Eles filmam sem um roteiro prévio, acompanham eventos na medida em que estes ocorrem. São os montadores que constroem uma estrutura e um ritmo para o material filmado. Em comum entre todos eles é a ideia de que o documentário deveria ser como "uma janela aberta para o mundo".

${ }^{10}$ BARSAM, 1992: 310. 


\section{O novo jornalismo}

$\mathrm{Na}$ década de 1950, o clima entre jornalistas era de grande insatisfação em relação às regras de objetividade do texto jornalístico. Em nome de uma suposta cientificidade, a imprensa americana havia adotado técnicas obrigatórias de redação como o lead (O quê? Quem? Como? Onde? Quando? Por quê?) e a pirâmide invertida (uma estrutura narrativa que prioriza uma ordem decrescente dos elementos mais importantes da notícia). A atividade jornalística se encontrava regida por um modo de captação, apuração e expressão muito bem demarcado, que deixava pouca margem de autonomia para os repórteres. $\mathrm{O}$ jornalismo não parecia apto a acompanhar um mundo em confronto consigo mesmo, recém-saído de uma guerra mundial.

Tom Wolfe, um então jovem repórter americano, sintetiza essa insatisfação em seus primeiros ataques contra talvez o maior representante da suposta "cientificidade" dos jornais, o colunista do "Times" Walter Lippmann. ${ }^{11}$ Jornalistas começariam a colocar em xeque as técnicas e a delimitação de fronteiras. Parecia evidente que as formas cunhadas em outras épocas não seriam suficientes para lhes permitir expressar o que viviam. Com eles, a imprensa vai buscar em um campo tangente, a literatura, e, mais especificamente, na ficção, elementos para a construção de um outro tipo de jornalismo. Nos Estados Unidos, publicações como a "Esquire", a "True" e, em especial, a "The New Yorker", e um grupo de jornalistas, entre eles Wolfe, Trumam Capote, Gay Talese, Lillian Ross, e Norman Mailer, engajaram-se em um movimento de ruptura e ampliação da atividade que seria batizado de "novo jornalismo".

Nestes primórdios ainda eclodia na imprensa americana o pioneirismo de John Hersey. Publicado em uma única edição da “The New Yorker' em 31 de agosto de 1946, "Hiroshima" é o relato do desastre causado por uma das duas bombas atômicas lançadas no Japão durante a guerra. O impacto da obra vinha do enfoque e da abordagem escolhidos por Hersey. "Hiroshima" humanizava a guerra por meio do relato de seis sobreviventes - duas mulheres e quatro homens, sendo um deles um estrangeiro no Japão. $\mathrm{O}$ autor aproximou a abstração ameaçadora de uma bomba atômica à experiência cotidiana dos leitores, enfatizando emoções em um texto simples, e deixando fluir o relato oral dos personagens.

Seis anos depois, "The New Yorker" publicaria um conjunto de reportagens intitulado "Produção $n^{\circ}$ 1512" (com o subtítulo "John Huston em Hollywood"). Lillian Ross, que já havia utilizado técnicas parecidas com as de Hersey em uma série de perfis (entre eles um famoso sobre Ernest Hemingway) acompanhou as filmagens de "A glória de um covarde" (1951), um filme dirigido por Huston e destruído pela máquina hollywoodiana. Ross explica ao seu editor: "Não sei se esse tipo de coisa já foi realizado antes, mas não vejo por que eu não deveria tentar uma história factual em forma de romance, ou talvez um romance factual”. ${ }^{12}$ A reportagem saiu pouco depois em

\footnotetext{
${ }^{11}$ Entre muitos ataques, Wolfe diz: "Durante 35 anos, Lippmann parecia não fazer nada além de ingerir o 'Times' todas as manhãs, ruminá-lo ponderosamente durante alguns dias e depois metodicamente defecá-lo na forma de uma gota de papa na testa de diversas centenas de milhares de leitores". WOLFE, 2005: 23.

12 CITADA por SUZUKI em ROSS, 2005: 10.
} 
livro ("Filme") e tornou-se mais um exemplo do exercício de recursos típicos da literatura de ficção na atividade jornalística.

O jornalismo sempre manteve uma relação de proximidade com a literatura. Mas desta vez, ela era apropriada, como afirma Fernando Resende (2002), com uma consciência de que nela seriam encontradas ferramentas para uma abertura das possibilidades narrativas do jornalismo, para transformá-lo em algo mais coerente com seu tempo. O novo jornalismo rompe então com duas das características básicas do jornalismo contemporâneo: a periodicidade e a atualidade ${ }^{13}$. Assume-se um elenco de temas muito vasto e uma liberdade de pautas tão flexível quanto a complexa e mutante realidade da civilização em acelerado processo de mudança. Enquanto Norman Mailer escreve sobre as primárias presidenciais, Joseph Mitchell se detém em perfis de personagens desconhecidos.

No entanto, o novo jornalista não ignora o que aprendeu no jornalismo diário. O que ele faz é desenvolver técnicas narrativas já presentes no jornalismo de tal maneira que acaba constituindo novas estratégias profissionais. Mas os princípios da redação, como, por exemplo, a apuração rigorosa, a abordagem ética e a capacidade de se expressar claramente, continuam atuantes e fundamentais - "o novo jornalismo, embora possa ser lido como ficção, não é ficção. É, ou deveria ser, tão verídico quanto a mais exata das reportagens", explica Talese. ${ }^{14}$

Em 1973, Tom Wolfe publicaria um manifesto em que constatava que algo estava acontecendo nos confins da esfera profissional da reportagem. Para ele, a ideia básica do novo jornalismo americano era evitar "o aborrecido tom bege pálido" que caracterizava a tal imprensa objetiva. O texto, segundo Wolfe, deve ter valor estético, valendo-se sempre de técnicas literárias. Gay Talese concorda: "O novo jornalismo permite, na verdade, exige uma abordagem mais imaginativa da reportagem". ${ }^{15}$

Este novo jornalismo é basicamente um jornalismo de imersão do repórter e precisão de dados e observações, que permite que a história venha à tona por meio de uma voz autoral e de um estilo. As narrativas do novo jornalismo concentram-se em recursos específicos e descrições minuciosas de lugares, feições, hábitos, gestos, comportamentos, objetos, etc.; procuram mostrar a realidade do mundo sobre outro ângulo; privilegiando o relato mais romanceado, mas sem comprometer o compromisso com os fatos.

Em uma reportagem sobre o ex-campeão mundial de peso pesado Joe Louis publicada em 1962, na revista "Esquire", Talese abre "Joe Louis: o Rei como Homem de Meia Idade" não com um lead, mas com um diálogo entre o lutador e sua mulher em um aeroporto de Los Angeles:

'Oi, amor!', falou Joe Louis para sua esposa, quando a avistou no aeroporto de Los Angeles à sua espera.

Ela sorriu, andou em sua direção e estava preste a se pôr na ponta dos pés para beijá-lo - mas parou de repente.

- 'Joe', disse ela. 'Onde está sua gravata?'

${ }^{13}$ Os editores da revista esperaram seis anos para o escritor entregar a primeira versão de "A sangue frio".

${ }^{14} \mathrm{e}^{15}$ TALESE, 2004: 9. 
- 'Ah, bem', disse ele sacudindo os ombros. 'Passei a noite inteira fora em Nova York e não tive tempo...

- 'A noite toda!', interrompeu ela. 'Quando você está aqui você só dorme, dorme, dorme'.

- 'Amor', disse Joe Louis com um sorriso cansado, 'eu sou um velho'.

- 'É', disse ela. 'Mas quando você vai a Nova York tenta ser jovem novamente. ${ }^{36}$

Em outro exemplo que também ilustra bem as novidades trazidas por estes novos jornalistas, Wolfe experimentou combinar o uso do ponto de vista convencional em terceira pessoa com um fluxo de consciência em seu segundo livro, "The eletrick kool-aid acid test". Para ele, a fórmula parecia a mais adequada para reproduzir a frenética fuga de um dos personagens mais notórios da contracultura americana: Ken Kesey, autor de "Um estranho no ninho", condenado a cinco anos de prisão por posse de maconha. Escondido no México, o escritor, paranoicamente, via em tudo e todos os policiais em seu encalço.

Mexa o rabo, Kesey. Mova-se. Suma. Dê no pé se manda desapareça desintegre-se. Corra. Rrrrrrrrum rumrumrumrumrum ou nós vamos ter uma tardia reprise mexicana da cena no telhado de São Francisco e sentar aqui com o motor girando e ver fascinados os tiras subindo uma vez mais para vir pegá você:

ELES ACABAM DE ABRIR A PORTA LÁ EMBAIXO, ESQUADRINHADOR DE ROTOR, ASSIM VOCE TEM 45 SEGUNDOS, PRESUMINDO QUE ELES SEJAM LENTOS E SORRATEIROS E SEGUROS DO QUE FAZEM. $^{17}$

É em exemplos como os citados acima que Wolfe acreditava ter o novo jornalismo aperfeiçoado o ápice das técnicas literárias no jornalismo. Doutor em estudos americanos pela Universidade de Yale, ele defendia que esse modo de narrar os fatos consistia em uma retomada, na literatura americana, de técnicas esquecidas do realismo dos tempos de Charles Dickens.

\section{Novos jornalistas e cineasta do direto: 'o mundo lá fora'}

Apenas um breve resumo das trajetórias de ambos os movimentos é suficiente para apontar diversas aproximações entre os novos jornalistas e os documentaristas do cinema direto. Tom Wolfe e Robert Drew, figuras de liderança do novo jornalismo e do cinema direto, respectivamente, começaram como jornalistas "convencionais" e pretendiam uma forma de narrar diferente da que se apresentava como hegemônica.

\footnotetext{
16 TALESE, 2004: 460.

17 CITADO por LIMA, 2004: 204.
} 
Wolfe e Drew foram espontânea e conscientemente influenciados pela literatura realista. Ambos negavam os definidores primários, os especialistas, os famosos entrevistados de plantão. Era preciso criar alternativas, ouvir o cidadão comum, a fonte anônima. Enquanto Wolfe chamava atenção para a necessidade do registro dos gestos cotidianos, o grande legado do cinema direto são as observações das pequenas cenas, dos acontecimentos miúdos: um senador dormindo, um grande compositor ensaiando em um quarto de hotel, um vendedor ambulante vivendo o fracasso em um restaurante de beira de estrada.

O novo jornalismo de Wolfe e o cinema direto de Drew também compartilhavam o interesse em trazer seus respectivos interlocutores para perto da ação. O primeiro ressalta em seu manifesto que "o principal problema de um repórter é estar com seu personagem o tempo suficiente para que as cenas se passem diante de seus olhos". ${ }^{18}$ Drew diz algo parecido ao citar o correspondente de guerra Ernie Pyle:

Um documentário não deve estar interessado em passar informações, mas sentimentos. Estou no momento fazendo um filme sobre bombardeios durante a Segunda Guerra ('De Dois Homens e Uma Guerra'). Quando eu estava na Itália, Ernie Pyle se juntou ao nosso grupo. Ele tinha muito jeito com as palavras e fazia as pessoas se sentirem lá. Essa ideia persistiu por toda a minha vida. ${ }^{19}$

Lillian Ross e Gay Talease também possuíam estilos e faziam uso de técnicas muito parecidas com as dos cineastas do cinema direto. Matinas Suzuzi jr. e Robert S. Boyton, por exemplo, usam uma expressão em geral aplicada ao cinema direto americano para descrever o trabalho de pesquisa de respectivamente Ross e Talese: "fly on the wall". Ambos os jornalistas procuravam diminuir ao máximo suas intervenções no meio registrado, nenhum dos dois usava gravadores, por vezes nem mesmo o bloquinho. Talease, por exemplo, sequer fazia entrevistas para algumas reportagens. Este foi o caso de uma de suas melhores matérias, "Frank Sinatra está resfriado": "Quando estava pesquisando para traçar o perfil de Frank Sinatra descobri que a cooperação - ou a falta dela - por parte da pessoa a ser retratada não importa muito, desde que o escritor possa acompanhar seus movimentos, ainda que à distância". ${ }^{20}$

O novo jornalismo e o cinema direto também são movimentos marcados por questionamentos de ordem ética. Ambos lidam com imprevisibilidades e devem negociar suas relações com as pessoas e suas vidas. Mas, em que medida cineastas e jornalistas buscam e trabalham o consentimento informado dos participantes e possibilitam que esse consentimento informado seja entendido e concedido? Até que ponto pode um cineasta ou um jornalista explicar as possíveis consequências de permitir que o comportamento seja observado por outros e representado para outros?

Os documentaristas do cinema direto eram extremamente eficientes em sua crença na espontaneidade e deixavam pouquíssimos rastros de manipulação.

18 WOLFE, 2005: 50.

${ }^{19}$ CITADO por ZUBER, 2004: 205.

20 TALESE, 2004: 13. 
Os novos jornalistas diziam respeitar os fatos, mas por vezes enveredavam por "reportagens psicológicas" e ousavam até transcrever o "pensamento" das pessoas com quem conversavam. Capote, por exemplo, foi seguidamente atacado. Uma das primeiras polêmicas em que foi protagonista girou em torno de uma questão moral e teve no influente crítico teatral inglês Kenneth Tynan o principal adversário. Tynan argumentava que Capote, ao longo dos anos cobrindo os desdobramentos legais do crime, teve tempo suficiente para provar a insanidade mental dos dois acusados e, assim, poderia ter evitado que eles fossem à forca. O crítico inglês sugeria que a execução teria sido uma atração a mais para o relato de Capote.

Os questionamentos não foram menores em relação ao cinema direto. Como o cineasta observativo adota um modo especial de presença "na cena", em que parece ser invisível e não participante, muitos levantaram questões como: quando o cineasta tem a intenção de intervir? E se acontecer alguma coisa que prejudique ou fira um dos atores sociais? Neste quesito, nenhum outro documentarista foi mais citado do que Frederick Wiseman. O cineasta pede consentimento verbal quando filma, mas supõe que, quando filma em instituições públicas, tenha o direito de registrar o que acontece. Ele nunca dá aos participantes qualquer controle sobre o resultado, não usa voz off nem entrevistas, e tampouco suporta quando percebe que a câmera está afetando o comportamento das pessoas filmadas.

Em "Titicut follies", Wiseman parece distante do seu objeto. Em determinada cena, um senhor idoso anda nu de um lado ao outro de sua cela-quarto. De repente, ele olha reprovador para a câmera como que a desafiando. Passados alguns segundos, ele desiste. A câmera vence. $\mathrm{O}$ interesse em encontrar pontos de incongruência no manicômio faz com que Wiseman trate alguns dos personagens que passam por sua câmera como peças de um

O novo jornalismo e o cinema direto também são movimentos marcados por questionamentos de ordem ética jogo. Essa missão que o cineasta se impôs como que expandiria seus limites éticos. Wiseman não se deixa "sujar" pelo o que acontece diante de si, ignorando todo o espetáculo que ele próprio cria para o seu objeto. João Moreira Salles se pergunta: "será que Wiseman não estaria perpetuando o mecanismo de desumanização das instituições que retrata?". ${ }^{21}$

O cinema direto é um cinema de fé na espontaneidade, que opera a partir de uma crença em uma realidade não-manipulada. No entanto, seria um exagero afirmar que a função estética do cinema era submetida a uma função epistêmica, que os documentaristas teriam embarcado na utopia da neutralização completa da equipe técnica, e que isso "poderia ser explicado pela origem e pelos objetivos jornalísticos da Drew Associates”. ${ }^{22}$ Para Da-Rin, por exemplo, o cinema direto substitui a legitimação artística do griersonismo por uma legitimação científica. Mas a citação de Pennebaker que ele usa para ilustrar tal afirmação - "Eu não acho que filmes devem proporcionar informação. Filmes devem ser antes de tudo algo de que você não duvide. Você confia naquilo que você vê" ${ }^{23}$ - poderia ser usada para dizer o contrário. Numa análise que

\footnotetext{
21 SALLES encerrou com essa provocação sua apresentação na abertura do festival É Tudo Verdade (2001), que trazia uma retrospectiva do cineasta americano.

22 DA-RIN, 2004: 140.
} 
englobe os filmes e outras entrevistas dadas por Pennebaker, a citação usada por Da-Rin apenas confirmaria o fato do cineasta assumir a dimensão de construção de seus documentários.

Pennebaker busca manter no seu produto final a sensação original evocada pela imagem da "realidade"; seus filmes são construídos para atingirem esse objetivo. Seus documentários são o resultado de uma certa organização, de uma certa estrutura que os constituem como verdadeiros para o espectador. Além do mais, Pennebaker sublinha que sua câmera é essencialmente subjetiva e conta o seguinte a respeito das filmagens de "Dont look back": "Eles entendiam que a câmera os estava registrando da maneira que eles se deixaram registrar. Eles estavam interpretando seus papéis e o faziam brilhantemente. Se o Dylan quisesse olhar direto para a câmera eu não tinha por que dizer para ele não fazê-lo". ${ }^{24}$

Os Maysles também tinham na montagem uma ferramenta fundamental e assumem as similaridades estruturais com o cinema ficcional. David Maysles, por exemplo, em entrevista a Jack Krool, revela que ele e a montadora Charlotte Zwerin trabalharam em "Caixeiro viajante" na construção e na condução de determinados sentimentos e conclusões, e que queriam deixar os "espectadores bastante deprimidos no fim do filme". Albert Maysles complementa: "Meus filmes são totalmente subjetivos. Esse dualismo objetividade/subjetividade, do meu ponto de vista, pelo menos em termos de cinema, não faz nenhum sentido. Meus filmes são respostas a determinadas experiências". ${ }^{25}$

$\mathrm{Na}$ verdade, essa condenação a respeito das aspirações de espelhamento da realidade do cinema direto e a associação que se costuma fazer entre essa "ingenuidade" e a origem e o objetivo jornalísticos do movimento está calcada muitas das vezes em uma concepção errada do que vem a ser a tal "objetividade" jornalística. Da-Rin parece se referir à objetividade jornalística em oposição à subjetividade, o que é um grande erro. A objetividade não surge para negar a subjetividade, mas por reconhecer a sua inevitabilidade. $O$ conceito de "objetividade", que passou a ser adotado no campo do jornalismo no início do século XX, está ligado originalmente à ideia de que os fatos são construídos de forma tão complexa que não se pode cultuá-los como a expressão absoluta da realidade. Em outras palavras, com essa ideologia da objetividade, os jornalistas substituíram uma fé simples nos fatos por uma fidelidade às regras e procedimentos. A objetividade jornalística não diz respeito ao jornalista, mas ao método por ele utilizado.

Ao longo dos anos, entretanto, o conceito foi perdendo seu significado original e hoje causa muita confusão, inclusive no campo do jornalismo, que, aliás, namorou por algum tempo a ideia do espelho. Entre as muitas bandeiras do novo jornalismo está certamente a retomada da definição original do termo, que na década de 50 andava sendo utilizado em nome de ideais cientificistas. Ross dizia que as escolhas subjetivas aparecem na eleição dos temas e personagens que serão apresentados, e no formato da composição; que os fatos devem imperar, mas que seu ponto de vista tem de estar implícito nos fatos descritos. Wolfe também afirmava a objetividade como o leme de seu trabalho como

${ }^{23}$ CITADO por DA-RIN, 2004: 140.

${ }^{24}$ PENNEBAKER em ROSENTHAL, 1971: 192.

25 MAYSLES em ROSENTHAL, 1971: 70. 
jornalista, mas um leme que de maneira nenhuma anulava ou condenava o uso de recursos ficcionais e o propósito de atrair e emocionar.

O que talvez seja mais "problemático", na verdade, é a própria noção de "realidade" a partir da qual tanto o cinema direto quanto o novo jornalismo operam. Ambos os movimentos estão baseados em uma tentativa de representar, o mais fielmente possível, uma realidade de um EUA em tempos de mudança. Esse compromisso com a construção de uma visão correspondente à realidade, de um "mundo real lá fora", une novos jornalistas e documentaristas do cinema direto. Ambos pressupóem a existência de uma realidade que não é fruto e nem depende da nossa percepção, e que é possível estabelecer um contato com esta realidade.

Entretanto, diversos autores já sublinharam de diferentes maneiras que o termo "realidade" deveria ser sempre conjugado no plural. Podemos ficar em dois exemplos. Ludwig Wittgenstein sustenta que nossa percepção do mundo é, fundamentalmente, derivada da linguagem que empregamos. É o que ele diz no "Tractatus Logico-Philosophicus": "Os limites de minha linguagem significam os limites de meu mundo". ${ }^{26} \mathrm{O}$ mundo, para ele, circunscreve-se àquilo que pode ser captado pela consciência, e nossa consciência apreende as coisas através da linguagem que empregamos e que ordena nossa realidade. Assim, o real será sempre produto da dialética, do jogo existente entre a materialidade do mundo e o sistema de significação utilizado para organizá-lo. Em "As palavras e as coisas" (2002), Michel Foucault traça uma história crítica da gênese, da extensão e dos limites das ciências humanas e inaugura a questão da perspectivação da modernidade, interrompendo a correspondência entre o homem e o mundo, o homem e ele mesmo, o homem e seus saberes. Para Foucault, a realidade está sempre em produção, efeito de uma série de práticas, discursos, instituições, técnicas, regras e espaços em constante interação e mutação.

Para Wolfe, o realismo é uma propriedade fundamental para o conhecimento. Para Drew, o cinema direto significava capturar a realidade em filme. Novos jornalistas e documentaristas desenvolveram métodos e técnicas que seriam capazes, segundo eles, de capturar uma realidade em vias de desconstrução. Maysles, por exemplo, em entrevista a Zuber, questiona: "Como eles eram chamados? A ideia básica deles era a de que não sabemos nada de maneira definitiva, concreta. Eles estavam corrompendo nossa confiança em se reunir verdades". ${ }^{27}$

O cinema direto estabeleceu uma continuidade não exatamente (ou pelo menos não em todos os seus adeptos) com uma ideologia documental cientificista, mas com uma ideia de realismo bazaniano ${ }^{28}$, um realismo que se afirma em uma dimensão ontológica. $\mathrm{O}$ novo jornalismo emerge num período em que a imprensa também parecia regida por ideais cientificistas na relação com os fatos. Se por um lado, esses novos jornalistas romperam com a ideia de uma transmissão não-expurgada da realidade; do outro eles levaram adiante a premissa de uma realidade passível de ser representada por meio de reportagens.

\footnotetext{
${ }^{26}$ WITTGENSTEIN, 1994: 246.

27 ZUBER, 2004: 226.

${ }^{28} \mathrm{Em}$ poucas palavras, o crítico e teórico francês Andre Bazin defende a ideia de que a especificidade do cinema não reside na capacidade de manipulação da montagem, mas no seu oposto, ou seja, no ajustamento plástico da imagem cinematográfica ao sentido da realidade. Ver BAZIN, 1992.
} 
Novos jornalistas e os cineastas do cinema direto tentavam recuperar uma noção mais tradicional de "real", de um "mundo lá fora". Ambos os movimentos expressavam ao mesmo tempo uma ruptura com suas respectivas tradições e uma agenda um tanto conservadora. $\mathrm{O}$ cinema direto e o novo jornalismo americanos redefiniram o documentário e o jornalismo, e criaram padrões e expectativas em relações às ideias de verdade, verossimilhança e objetividade. O realismo, em sua concepção tradicional, estava mais uma vez tentando manter seu status. Apesar de ambos os movimentos tentarem usar o melhor dos dois mundos, afirmando a possibilidade de se desenvolver uma narrativa que atinja qualidades literárias ou ficcionais sem, no entanto, ser necessariamente literatura ou ficção; "ficção" e "não-ficção" ainda parecem aqui perfeitamente diferenciáveis um do outro.

\section{Referências bibliográficas}

CAPOTE, Truman. A sangue frio. São Paulo: Companhia das Letras, 2003.

DA-RIN, Silvio. Espelho partido: Tradição e transformação do documentário. Rio de Janeiro: Azougue Editorial, 2004.

BAZIN, Andre. O que é o cinema?. Lisboa: Livros Horizontes, 1992.

FOUCAULT, Michel. As palavras e as coisas. São Paulo : Martins Fontes, 2002.

HERSEY, John. Hiroshima. São Paulo: Companhia das Letras, 2002.

LIMA, Edvaldo Pereira. Páginas ampliadas. Barueri, SP: Manole, 2004.

Nieman Reports, Vol.54, N³, Fall 2000. "Narrative journalism: reporting and writing in a different voice". Disponível on-line em: http://www.nieman.harvard.edu/reports/00-3NRfall/NRfallo0.pdf

RESENDE, Fernando. Textuações: ficção e fato no novo jornalismo de Tom Wolfe. São Paulo: Annablume, 2002.

ROSENTHAL, Alan. New documentary in action. California: University of California Press, 1971.

ROSS, Lillian. Filme. São Paulo: Companhia das Letras, 2005.

TALESE, Gay. Fama e anonimato. São Paulo: Companhia das Letras, 2004. WINSTON, Brian. "A maldição do jornalístico na era digital". In: MOURÃO, Maria Dora \& LABAKI, Amir (orgs). O cinema do real. São Paulo: Cosac \& Naify, 2005.

WITTGENSTEIN, Ludwig. Tractatus Logico-Philosophicus. São Paulo: Edusp, 1994.

WOLFE, Tom. Radical Chique e o novo jornalismo. São Paulo: Companhia das Letras, 2005.

ZUBER, Sharon. "Re-Shaping Documentary Expectations: New Journalism and Direct Cinema". Tese de doutorado em Comunicação da College of William and Mary, 2004. 